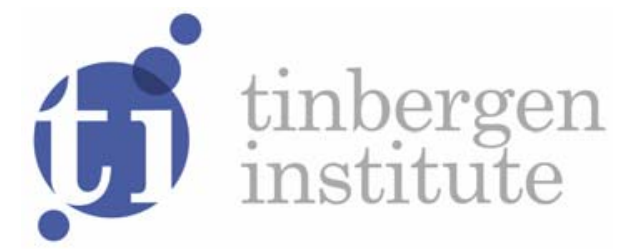

\title{
A Cost-Effectiveness Analysis For Incineration Or Recycling Of Dutch Household Plastics
}

\author{
Raymond Gradus ${ }^{1}$ \\ Rick van Koppen² \\ Elbert Dijkgraaf3 \\ Paul Nillesen²
}

' Faculty of Economics and Business Administration, VU University Amsterdam, the Netherlands;

2 PricewaterhouseCoopers;

${ }^{3}$ Erasmus School of Economics, Erasmus University Rotterdam, and Tinbergen Institute, the Netherlands. 
Tinbergen Institute is the graduate school and research institute in economics of Erasmus University Rotterdam, the University of Amsterdam and VU University Amsterdam.

More TI discussion papers can be downloaded at http://www.tinbergen.nl

Tinbergen Institute has two locations:

Tinbergen Institute Amsterdam

Gustav Mahlerplein 117

1082 MS Amsterdam

The Netherlands

Tel.: +31(0)20525 1600

Tinbergen Institute Rotterdam

Burg. Oudlaan 50

3062 PA Rotterdam

The Netherlands

Tel.: +31(0)10 4088900

Fax: +31(0)10 4089031 


\title{
A cost-effectiveness analysis for incineration or recycling of Dutch household plastics
}

\author{
R.H.J.M. Gradus, VU University Amsterdam \\ R.J. van Koppen, PricewaterhouseCoopers (PwC) \\ E. Dijkgraaf, Erasmus University Rotterdam/Tinbergen Institute \\ P.H.L. Nillesen, PricewaterhouseCoopers Advisory N.V. (PwC)
}

Version: 19 May 2016

Correspondence to: R. Gradus, VU University Amsterdam, Faculty of Economics and Business Administration, De Boelelaan 1105, 1081 HV Amsterdam, the Netherlands, email: r.h.j.m.gradus@vu.nl

\begin{abstract}
The cost-effectiveness of plastic recycling is compared to energy recovery from plastic incineration in a waste-to-energy plant using data for the Netherlands. Both options have specific benefits and costs. The benefits of recycling are the avoidance of both $\mathrm{CO}_{2}$ that otherwise would be emitted during incineration and the production of virgin (new) material. There are significant costs, such as collection costs and recycling costs involved for plastic recycling by municipalities. The benefits of energy recovery from plastic are heat and electricity production leading to fewer emissions in the regular energy production sector, but this requires a waste-to-energy plant with the associated capital investments. Summing all the costs and benefits results in an implicit $\mathrm{CO}_{2}$ abatement price of 172 Euro per tonne of $\mathrm{CO}_{2}$ in case of plastic recycling. In general, this implicit price is much higher than current (or historic) ETS prices, the estimated external costs of $\mathrm{CO}_{2}$ emissions, or alternatives to reduce $\mathrm{CO}_{2}$ emissions (e.g. renewable energy). A sensitivity analysis shows that this conclusion is robust.
\end{abstract}

JEL classification: H43, Q38, Q42

Keywords: recycling, incineration, plastics, cost-effectiveness analysis 


\section{INTRODUCTION}

Lack of space and a growing environmental awareness forced Dutch governments to take measures from the early Eighties to reduce the landfilling of unsorted waste and to stimulate incineration and recycling (see Dijkgraaf (2004)). In 2014, the Netherlands recycled 24 percent and composted 27 percent of its municipal waste - and most of the remainder was incinerated to recover energy (mostly electricity). The incineration facilities are amongst the most efficient in the world, with high energy recovery and competitive gate fees. Although there was some discussion at the beginning of this century whether the disposal of waste should be considered from a cost-benefit perspective (see Dijkgraaf and Vollebergh (2004)), the Dutch government remains committed to its strict policy to stimulate waste recycling and incineration.

As in many European countries, Dutch waste incineration has been disputed and some parties even advocate zero-waste economy policies (see Seltenrich (2013)). The advocates of more recycling point out in the direction of Germany, which has relatively less waste incineration and a recycling rate of $48 \%$ - two times the Dutch rate. In the past decade, Dutch efforts to stimulate collection of recyclable waste, especially at the source, have been intensified. Dijkgraaf and Gradus (2016) show that between 1998 and 2012 there was an increase in facilities at drop-off centres for collecting different waste streams such as paper, glass and textiles, and many municipalities introduced curbside collection and unit-based pricing to stimulate recycling. In recent years, recycling of plastics drew additional attention. Per 2016 free plastic bags in shops are forbidden. Since 2009 most Dutch municipalities separately collect plastic packaging and are financially compensated by the packaging industry - similar to other European countries (see Da Cruz et al. (2014)).

As a consequence, more and more Dutch plastics are recycled and therefore improvements can be obtained related to 'Global Warming' (or reducing $\mathrm{CO}_{2}$ emissions), if we compare it waste incineration. However, the infrastructure costs for the collection and separation of household plastic currently outweigh the revenues that are generated from the sale of recycled plastic. Therefore, in the Netherlands a municipality is compensated for this deficit by the packaging industry and gets a 
contribution of 670 Euro per tonne of collected household plastic. In addition, treatment costs depend on the quality of the final plastic material delivered. Producing plastics for high quality industrial purposes will require further separation and processing to meet the standards. Incineration of plastic waste generates more than three times the energy compared with other materials (see also Morris (2006)). This increases the costs of incinerating waste with less plastic. In other words, decreasing the plastic content of municipal waste lowers the energy output per unit of input and thus increases incineration costs. Both the separation and treatment of plastics is costly when compared to the incineration alternative. This provides the basis for an interesting debate between the costs and benefits of recycling versus the incineration of plastics.

Hopewell et al. (2009) show that incineration of plastic is less prevalent form of wastemanagement strategy than the recycling of plastics at household level. Nevertheless, they also point out that for highly mixed plastics energy-recovery may be the most suitable option. As far as we know a cost-effectiveness analysis comparing household plastic recycling, with plastic collected separately at source (i.e. household level), to the recovery of energy through plastic incineration has not been performed. This paper attempts to fill that gap. Both options - plastic recycling and energy recovery from plastic - have specific benefits and costs. The benefit of recycling is the avoided $\mathrm{CO}_{2}$ that would otherwise be released during incineration and during the production of plastics (as plastic is based on hydrocarbons). At the same time, there are significant costs involved with separate plastic collection at household level by municipalities (e.g. collections costs) and the production of new (recycled) plastic raw materials. The benefits of energy recovery from plastic incineration are heat and electricity production. The associated costs are related to the capital and maintenance expenditure of a wasteto-energy facility. To determine the cost effectiveness of plastic recycling the benefits, costs and environmental impact - expressed in $\mathrm{CO}_{2}$ emissions - are compared to the alternative, energy recovery from plastic incineration. The implicit cost of the $\mathrm{CO}_{2}$ reduction is calculated by comparing the difference in the net costs with the difference in net $\mathrm{CO}_{2}$ emissions. This (implicit) price can then be compared with other options to achieve $\mathrm{CO}_{2}$ reductions. We show that our derived implicit price is higher than both current and historic ETS prices, the external costs, or other alternatives, such as 
renewable power production. We includes a sensitivity analysis to test the robustness of our conclusions and we demonstrate that, in general, this implicit price is indeed high in comparison.

The rest of this paper is organized as follows. Section I describes the producer responsibility for plastic packaging in the Netherlands. Section II presents the cost effectiveness analysis, where we first present the chosen methodology and the data, followed by the analysis itself. Section III presents the sensitivity analysis, and finally section IV concludes, discusses policy implications, and makes suggestions for further research.

\section{DUTCH EXTENDED PRODUCER RESPONSIBILITY}

As a result of the European Directive on Packaging and Packaging Waste, it is the responsibility of producers to separate plastic packaging waste. Similar to Belgium, France and Germany, a “green dot” company ('Afvalfonds Verpakkingen’) is in charge of execution of this legislation (see also Marques and da Cruz (2015)). This company collects a financial contribution paid by the retail sector and packaging industry and transfers this to municipalities, which are in charge of collecting household plastics.

The Netherlands has implemented this European legislation strictly. In 2014, 50\% of (packaging) plastics was recycled and in 2022 this goal is 52\%, which is almost double compared to the current EU legislation but more in line with the plans of the EU for $2025 .{ }^{1}$ In order to comply with the ambitious recycling targets, the green dot company was granted a license to manage the household flow of plastics. Its task is to promote, coordinate and finance the collection, sorting and recycling of municipal (packaging) plastic. The (packaging) industry in the Netherlands has joined this green dot company and pays a fee to the fund according to the level of plastic production. Most companies pay a fixed contribution for products such as body care, cleaning etc. In the Netherlands, municipalities are responsible for the collection and treatment of municipal waste, such as plastic. In 2015, there were 393 municipalities in the Netherlands, which

\footnotetext{
${ }^{1}$ According to a proposal on 20/04/2016, the Commission proposed a 2025-target for recycling 55\% of (packaging) plastics by 2025. As the Netherlands has already reached this goal in 2015, an environmental groups as Natuur\&Milieu propose 52\% in 2017 as target for plastics recycling (see KIDV (2016)).
} 
received a financial contribution from the green dot company. ${ }^{2}$ The financial contribution was 670 Euro per tonne plastic in 2015. This is more than the compensation in Belgium and France, but less than Germany.

Based on 2010-data by Marquez and Cruz (2015), the green dot fees of these countries differ widely. For Belgium and France this was respectively 220 and 245 Euro per tonne plastic, for Germany it was (on average) almost 1,430 Euro per tonne. ${ }^{3}$ Marquez and Cruz (2015) discuss that these differences are driven in part by the scope of recycling policies, and thus which plastics are recycled. In Germany, for example, mixed plastics are recycled, whereas in Belgium only plastic bottle and flasks, metallic packaging, and drink cartons are separated. In the case of Belgium only plastic of higher quality is separated, which increases the revenues from the sale of secondary plastic, and subsequently leads to lower compensation tariffs. This implies that if recent European plans become legislation, green dot fees in countries like Belgium will need to be raised, making our cost-effectiveness analysis of the Dutch market relevant for other European countries.

Dutch local authorities are responsible for collecting household plastic, but are allowed to decide how these plastics are collected. In Dijkgraaf and Gradus (2016), it is shown that $37 \%$ of municipalities collect plastic at the curbside, while in the remaining municipalities citizens have to bring plastics to collection points nearby schools and shopping centres. Over half of the curbside municipalities (59\%) collect plastics once a month and a quarter (27\%) twice a month. In some municipalities - especially large cities such as Amsterdam - plastics are not yet collected separately. In the case of Amsterdam, an exemption was granted by the Dutch Ministry of Infrastructure and Environmental Affairs (Ministerie van Infrastructuur en Milieu). In 2012, 49 municipalities (12\%) did not collect any plastics separately, although this exemption is limited in time. In addition, in some municipalities, especially in the north of the

\footnotetext{
${ }^{2}$ Also other packaging material such as glass receive a contribution from Afvalfonds Verpakkingen, but the contribution for plastics is the most important.

${ }^{3}$ This is based on table 3.3 for Belgium, table 3.5 for France and table 3.12 for Germany and taking into account that that 1 ton is 0.907 (metric) tonne. It should noticed that this fee is not mandatory for Germany as it is private arrangement between industry and several green dot companies and is based on the last public available list. For other countries discussed in this book, their system is less comparable.
} 
Netherlands, plastics are separated industrially after unsorted municipal solid waste is collected at the curbside. However, this post-separation is not stimulated by central government and even not registered in the official accounts. In section IV we will discuss this issue of post-separation.

In the Netherlands all costs for sorting and treating packaging waste are fully reimbursed by the (packaging) industry (see Marques and Da Cruz (2015)). Each producer has to declare the packaging waste it produces, whereas some products, such as body care or cleaning products, have a fixed-fee scheme. To avoid administrative costs, small supermarkets and packaging companies are exempted for this fee. In 2015, approximately 2500 Dutch companies paid such a fee. These producers pay a fixed contribution per product, which is normally charged to the consumers. ${ }^{4}$ In 2015 , the costs for plastic recycling were 120 million Euros; equivalent to approximately 15-16 Euro per household.

\section{COST-EFFECTIVENESS ANALYSIS}

\section{II.1 Method and data}

Dutch waste-to-energy plants employ state-of-the-art technology, which filters out most air pollutants as $\mathrm{SO}_{\mathrm{x}}$ and $\mathrm{NO}_{\mathrm{x}}$. This is also the result of additional environmental standards in excess of minimum European requirements. Incineration of plastics compared with the incineration of unsorted municipal solid waste emits fewer pollutants, such as $\mathrm{SO}_{\mathrm{x}}$ and $\mathrm{NO}_{\mathrm{x}}$ (Eriksson et al. (2005)). Therefore, we focus on $\mathrm{CO}_{2}$ emissions and we calculate the difference of $\mathrm{CO}_{2}$ emissions and net-costs including benefits of recycled plastics and energy recovery. This method gives the implicit price for avoiding one tonne $\mathrm{CO}_{2}$, which can be compared with other options.

To assess the cost effectiveness of the collection and recycling of plastic, the specific benefits and costs of both options are compared. In Table 1 the core information is specified as collected from public sources. In the next section we explore this information in a cost-effectiveness analysis.

\footnotetext{
${ }^{4}$ Marquez and Da Cruz (2015, table 3.2) show that this fixed contribution for Belgium can range from $€$ 0.17 for TV to $€ 0.0006$ for tobacco.
} 
Table 1. Core information of the analysis

\begin{tabular}{|c|c|c|}
\hline Input & Figure & Source \\
\hline \multicolumn{3}{|l|}{ Plastic characteristics } \\
\hline Plastic heating value & $29 \mathrm{MJ} / \mathrm{kg}$ & $\begin{array}{l}\text { Bergsma et al. (2011): Range of } 23 \text { - } 42 \\
\text { MJ/kg }\end{array}$ \\
\hline \multicolumn{3}{|c|}{ Waste incineration parameters } \\
\hline $\begin{array}{l}\text { Electricity generation } \\
\text { efficiency }\end{array}$ & $21 \%$ & Based on Rijkswaterstaat (2013) \\
\hline Heat production efficiency & $20 \%$ & Based on Rijkswaterstaat (2013) \\
\hline Collection costs & $56 € /$ tonne & NVRD (2014) \\
\hline Incineration costs & $125 € /$ tonne & $\begin{array}{l}\text { Integral cost price based on Waste and } \\
\text { Resources Action Programme (WARP) } \\
\text { average UK gate fee in } 2015^{5}\end{array}$ \\
\hline $\begin{array}{l}\mathrm{CO}_{2} \text { emissions plastic } \\
\text { incineration }\end{array}$ & 2599 kg/tonne & $\begin{array}{l}\text { Average of } 2188 \mathrm{~kg} / \text { tonne and } 3010 \\
\mathrm{~kg} / \text { tonne; based on Benner et al. (2007) }\end{array}$ \\
\hline \multicolumn{3}{|l|}{ Recycling parameters } \\
\hline Plastic recovery percentage & $75 \%$ & $\begin{array}{l}\text { Association of Dutch municipalities } \\
\text { (VNG) (2014b) }\end{array}$ \\
\hline $\begin{array}{l}\text { Collection remuneration } \\
2015\end{array}$ & $408 € /$ tonne & $\begin{array}{l}\text { Association of Dutch municipalities } \\
\text { (VNG) (2014a) }\end{array}$ \\
\hline Post-collection 2015 & $204 € /$ tonne & $\begin{array}{l}\text { Association of Dutch municipalities } \\
\text { (VNG) (2014a) }\end{array}$ \\
\hline Net market costs 2014 & $58 € /$ tonne & $\begin{array}{l}\text { Association of Dutch municipalities } \\
\text { (VNG) (2014b) }\end{array}$ \\
\hline $\begin{array}{l}\mathrm{CO}_{2} \text { emission plastic } \\
\text { recycling }\end{array}$ & $271 \mathrm{~kg}$ CO2/tonne & $\begin{array}{l}\text { Average of } 283 \mathrm{~kg} / \text { tonne and } 259 \\
\mathrm{~kg} / \text { tonne based on Benner et al. (2007) }\end{array}$ \\
\hline \multicolumn{3}{|l|}{ Transport parameters } \\
\hline $\begin{array}{l}\text { Distance to waste } \\
\text { incineration }\end{array}$ & $100 \mathrm{~km}$ & Assumption: 50 km twice \\
\hline $\begin{array}{l}\text { Distance to sorting } \\
\text { installation }\end{array}$ & $100 \mathrm{~km}$ & Assumption: $50 \mathrm{~km}$ twice \\
\hline $\begin{array}{l}\text { Distance to granulate } \\
\text { producer }\end{array}$ & $200 \mathrm{~km}$ & $\begin{array}{l}\text { Assumption: Granulate producer based in } \\
\text { Germany }\end{array}$ \\
\hline $\begin{array}{l}\mathrm{CO}_{2} \text { emission of road } \\
\text { transport }\end{array}$ & $0.08 \mathrm{~kg} / \mathrm{kmtonne}$ & Visser \& Smit Bouw (2010) \\
\hline Costs of road transport & $0.04 € /$ kmtonne & Based on Groen et al. (2012) \\
\hline \multicolumn{3}{|l|}{ Price parameters } \\
\hline Electricity price & $50 € / M W h$ & Based on average cal. 2015 APX prices \\
\hline Heat and steam price & $6 € / G J$ & Ministry of Economic Affairs (2013) \\
\hline
\end{tabular}

There is no publicly-available information about the costs of collection and recycling of plastics in the Netherlands. We therefore use the remuneration fees that are provided to

\footnotetext{
${ }^{5}$ See http://www.wrap.org.uk/content/latest-gate-fees-trends-revealed-wrap. Hereby, we take the average of 65 and 132 English Pound and convert it into Euros.
} 
municipalities as proxy for the actual costs (Afvalfonds Verpakkingen). These fees are based on negotiations between the green dot company and the Association of Dutch municipalities (VNG). Further, the remuneration provided by the green dot company is a fixed fee per tonne per municipality for source-separated plastics. It is therefore an average across municipalities - implying that some municipalities may be compensated in excess of actual costs and vice versa. We view the remuneration fees as the best available proxy of actual costs. As this approach is a best guess of the costs, we test the sensitivity of the results to changes in the fees (see section III).

We assume that one tonne of mixed plastic, which is collected and transported to a recycling company, is based on the mass balance of separated plastic from households. Generally speaking, this source is more polluted than separated plastics from businesses. The recycling rate for this collected mixed plastic is 75 percent and, therefore, 25 percent of the collected household plastic is still used for energy recovery (Association of Dutch municipalities (2014b)). With the removal of plastic waste from unsorted waste, a loss of heat and electricity is created that would otherwise be produced by the waste-to-energy plant. We assume that the energy content of plastic is purchased at market prices - adjusted for conversion losses. The conversion efficiencies are based on the average efficiencies of Dutch waste-to-energy plants as indicated by Rijkswaterstaat $(2013)^{6}$.

If plastic is incinerated, it is not collected separately. To make it comparable with recycling, the calculations are based on one tonne of mixed plastic, but now produced from virgin material. These are presented as opportunity costs of incineration. If plastic is recycled, less energy is produced by waste-to-energy plants. To make it comparable with incineration, the calculations are based on the same energy output, but now produced through regular electricity generation. These are presented as opportunity costs of recycling. The full cost of the waste-to-energy plant is based on public information on investments and indications of yearly operational costs of processing waste. The revenues for electricity and heat are estimated based on available market

\footnotetext{
${ }^{6}$ For the Netherlands, the energy content of plastics is between 22.95 and $42.47 \mathrm{MJ}$ for 1 kilogram plastics (CE Delft (2011)). We assume a conservative $29 \mathrm{MJ} / \mathrm{kg}$ for plastic in the analysis. The energy content of $1 \mathrm{~kg}$ mixed household waste is about $9 \mathrm{MJ}$ (Rijkswaterstaat (2013)).
} 
data.

\section{II.2 The cost-effectiveness analysis}

In Table 2 costs and revenues are given for plastic recycling and energy recovery from plastics.

Table 2. Net costs of recycling and incineration in $€ /$ tonne plastic

\begin{tabular}{lcc}
\hline & Recycling & Incineration \\
Collection and transport costs & 408 & 60 \\
Net-treatment costs & 262 & 6 \\
Sub-total & 670 & 66 \\
Opportunity costs energy & 90 & \\
Opportunity costs plastics & & 495 \\
Total & 760 & 561 \\
\hline
\end{tabular}

First, the private costs of collection and treatment are taking into account. For waste incineration, the transport costs are 4 Euro per tonne and the collection costs are 56 Euro per tonne, which sum up to 60 Euro per tonne. For recycling, the collection and transport costs are 408 Euro per tonne. Because the fees of the green dot company are a total compensation for collection and transportation, a specification of these costs for recycling is not possible. It should be noted that collection and transportation costs of separated plastics are substantially higher than for normal waste. This is due to the fact that the density of plastics is considerably lower than for normal waste. In other words, more transport is needed per tonne for plastic than for more dense waste streams. Furthermore, in most municipalities a separate infrastructure of collection points is needed. This infrastructure requires a substantial upfront investment and regular extra collection costs for trucks and workers. Since the volume of separately collected plastic is rather low, this results in high costs per unit collected.

Second, the net treatment costs are given, which are based on the costs of treatment less the revenues generated by the sale of products. Also the net treatment costs of plastic recycling are substantially higher than for incineration. We take into account the 
revenues for secondary plastics in case of recycling and energy in case of incineration. The net treatment costs are 262 Euro per tonne of plastic for the recycling option, while the net treatment costs are 6 Euro per tonne for the incineration option ${ }^{7}$. To sum up, total (monetary) costs are 670 Euro per tonne of plastic for the recycling option, while the costs for energy recovery are only 6 Euro per tonne.

Third, we should take into account the missed opportunity of recycling, in case of plastic incineration, and energy recovery in case of plastic recycling. In other words, in case plastic is source-separated and no longer incinerated there is an energy deficit, which needs to be compensated. Alternatively, in case plastic is not source-separated and recycled but incinerated, there is a secondary plastic deficit, which needs to be taken into account. In case of plastic recycling an energy deficit of 90 Euro per tonne is created - the equivalent energy value of the plastic that is separated at recycled, but would otherwise have been used for energy recovery. ${ }^{8}$ In the case of plastic incineration a deficit would is created in the volume of secondary plastic (recycled plastic). The value of recycled plastic that is lost due to incineration is 495 Euro per tonne. ${ }^{9}$

To sum up, the net costs of one tonne of plastic recycling are considerable higher than for energy recovery. The total cost for recycling plastic are 760 Euro per tonne and for energy recovery 561 Euro per tonne, which results in a difference of 199 Euro per tonne.

In Table $3 \mathrm{CO}_{2}$ emissions of both options are presented.

\footnotetext{
${ }^{7}$ The net costs of energy recovery are based on costs of $€ 125$ and revenues from generated electricity of $€ 85$ and revenues from generated heat of $€ 35$.

${ }^{8}$ See footnote 7 for the revenues per tonne plastic from generated electricity and from generated heat. We should take $75 \%$ of this as we assume in the recycling case that $25 \%$ of plastics is still part of unsorted waste.

${ }^{9}$ The base price of $€ 495$ per tonne is based on the average 2014 prices extracted from www.plasticker.de, accessed on February 2015 weighed by the household plastic volume mix.
} 
Table 3. $\mathrm{CO}_{2}$ emission of recycling and incineration in tonne $\mathrm{CO}_{2}$ per tonne plastic

\begin{tabular}{lcc}
\hline & Recycling & Incineration \\
Energy recovery & 0.65 & 2.60 \\
Recycling & 0.20 & \\
Transport & 0.02 & 0.01 \\
Sub-total & 0.87 & 2.61 \\
Opportunity emissions energy & 0.78 & \\
Opportunity emissions plastics & & 0.20 \\
Total & 1.66 & 2.82 \\
\hline
\end{tabular}

Based on Benner et al. (2007), the incineration of one tonne plastic yields 2.6 tonnes of $\mathrm{CO}_{2}$. As $25 \%$ of the recycled household plastics are burned as well, separating one tonne plastic yields 0.65 tonne $\mathrm{CO}_{2}$. Moreover, plastic recycling is an advanced industrial process that emits some $\mathrm{CO}_{2}$ as well, mostly due to the energy consumed. Also based on Brenner et al. (2007), we assume that one tonne of plastic yields 0.2 tonne $\mathrm{CO}_{2}$. In addition, the transport of plastics and unsorted yields some $\mathrm{CO}_{2}$ emissions, although their amount is relatively low.

The opportunity emissions are based on the most common alternative production process for producing either energy or secondary plastic granulate. For the generation of electricity, this is the average generation mix in the Netherlands, including renewable and conventional production. For the generation of heat the most common alternative process is the use of gas turbines. We assume that the opportunity emissions for secondary plastic granulate are the typical emissions of plastic recycling as no other process can generate this quality of plastic granulate.

From Table 3 it follows that the $\mathrm{CO}_{2}$ emissions from the energy recovery option are 1.16 tonnes higher than for the recycling option. This difference is mainly explained by the higher emissions of $\mathrm{CO}_{2}$ if plastic is incinerated. By using the difference in costs and the difference in $\mathrm{CO}_{2}$ emissions between both options, the cost-effectiveness of plastic recycling can be calculated in terms of a $\mathrm{CO}_{2}$ price. This means that the shadow 
price of one tonne of $\mathrm{CO}_{2}$ reduction by means of plastic recycling is equal to 172 Euro (199 Euro / 1.16 tonnes of $\mathrm{CO}_{2}$ ).

Let us compare this implicit price with other prices and an important alternative. During early 2016, the market price for $\mathrm{CO}_{2}$ emissions in the European Emissions Trading scheme (ETS) was approximately 6 Euro per tonne. ${ }^{10}$ This low price can be explained by the surplus of rights after the second trading period and the European crisis (see also Bel et al. (2015)). It is clear, however, that the shadow price of recycling plastic is much higher than the current (or historic) ETS price. If we take 50 Euro per tonne $\mathrm{CO}_{2}$ as an average value for the social cost of carbon emissions, this is still substantially lower than the shadow price of recycling plastic. ${ }^{11}$ As Tol (2008) shows this estimate depends on the discount rate and the weight of equity (between countries). In this meta-study, he also points that the distribution of the social cost of carbon ${ }^{12}$ is a fat right tail distribution, suggesting that there is a chance that total social costs are even larger than the price of one tonne of $\mathrm{CO}_{2}$ reduction by means of plastic recycling. Therefore, from a policy perspective, it is important to compare it with real alternatives as wind or solar energy or $\mathrm{CO}_{2}$ sequestration. Based on recent long-term calculations it was demonstrated that the costs of reducing one tonne CO2 is 29 Euro for wind and 81 Euro for solar. ${ }^{13}$ One of the more expensive options in the energy sector - $\mathrm{CO}_{2}$ capture and storage (CCS) in the North Sea -costs between 80 and 90 Euro per tonne of $\mathrm{CO}_{2}$ (Roller (2011). The cost of this option is still substantially lower than our shadow price of emissions reductions through recycling plastic. In other words, the $\mathrm{CO}_{2}$ emission reduction achieved by plastic recycling is expensive when we compare this with conventional $\mathrm{CO}_{2}$ prices and the currently being examined technologies within the energy sector.

\section{THE SENSIVITY ANALYSIS}

\footnotetext{
${ }^{10}$ For an overview of prices see http://www.investing.com/commodities/carbon-emissions (accessed on February 28, 2016).

${ }^{11}$ This is based on EEA (2008), which uses a low value of 19 euro and a high value of 80 euro. Note, however, that EU (2014) uses a price of only 33 euro per tonne of $\mathrm{CO}_{2}$ for the social cost.

12 Hereby, he uses a Kernel-distribution.

${ }^{13}$ Assuming a long term electricity price of 0.05 euro per $\mathrm{kWh}$, the current subsidy in the Netherlands for solar electricity is 0.073 euro and for wind 0.026 euro. Using the emission of $\mathrm{CO}_{2}$ for old coal fired electricity plants, the plants that are substituted for green energy, of 900 gram per $\mathrm{kWh}$, the implied $\mathrm{CO}_{2}$ price is respectively 81 and 29 euro per tonne $\mathrm{CO}_{2}$ (see also Greenpeace (2015).
} 
In a cost effectiveness analysis it is important to conduct such an analysis under a set of alternative reasonable assumptions to test whether our main conclusion is robust. The sensitivity of the cost effectiveness is reviewed using three scenarios. The results are presented in Table 4, after the presentation of the basic scenario.

In section II we assume that the $\mathrm{CO}_{2}$ emissions of missed energy recovery in case of the recycling scenario are based on the average energy mix in the Netherlands. In the first sensitivity scenario it is assumed that the purchased energy is fully $\mathrm{CO}_{2}$ neutral (which decreases the corresponding $\mathrm{CO}_{2}$ emissions from 0.78 per tonne to 0 per tonne in Table 3). ${ }^{14}$ In this case, the difference in $\mathrm{CO}_{2}$ emissions will be lower in favour of energy recovery and thus the emission gap increases, but the costs stay the same (see Table 4).

Table 4. Costs of $\mathrm{CO}_{2}$ reduction per scenario

\begin{tabular}{lccc}
\hline & $\begin{array}{c}\text { Cost gap } \\
(\boldsymbol{(})\end{array}$ & $\begin{array}{c}\mathbf{C O}_{2} \text { emission } \\
\text { gap (tonne) }\end{array}$ & $\begin{array}{c}\text { Costs of } \mathrm{CO}_{2} \\
\text { reduction } \\
\text { (€/tonne) }\end{array}$ \\
Base scenario & 199 & 1.16 & 172 \\
Scenario 1: Purchasing $\mathrm{CO}_{2}$ neutral energy & 199 & 1.94 & 103 \\
Scenario 2: Plastic price increase +10\% & 100 & 1.16 & 86 \\
Scenario 3: Decrease of fees to 2019-intention & 79 & 1.16 & 68 \\
\hline
\end{tabular}

In the first scenario, the cost effectiveness of recycling versus incineration is 103 Euro per tonne of $\mathrm{CO}_{2}$. Even with full renewable energy as a replacement of the energy produced by plastic incineration, the price per tonne $\mathrm{CO}_{2}$ is still high and above normal options.

In the second sensitivity scenario we make a different assumption about the plastic production market. ${ }^{15}$ Improving the market for secondary plastic (for example, by using more attractive applications) or improving the quality of the output (through targeted

\footnotetext{
${ }^{14}$ An alternative is that the plastic recovery percentage will increase from $75 \%$ to $90 \%$. In that case the $\mathrm{CO}_{2}$ of recycling will be lower, but costs will increase as well. Therefore, the cost-effectiveness is somewhat higher.

${ }^{15}$ It should be noted that recycling plastics delivers secondary supplies plastic, which not directly competes with primary plastic. An analysis of the correlation of the market prices of secondary plastic and the oil prices, shows that the prices of secondary plastic are only marginally dependent on the price of oil. The price for secondary plastic granulate is lower than the price for virgin material as the use of secondary plastic granulate is limited due to a lower quality. Secondary plastic granulate can therefore not be used as replacement for virgin material, without substantial costly quality improvements.
} 
innovations in the recycling production process), can increase the yield of secondary plastics and thus improve the cost effectiveness. In the second sensitivity scenario, we will assume that the price of secondary plastic will rise with 10 percent from 495 Euro to 544 Euro per tonne. In this scenario, the cost effectiveness decreases from 172 Euro per tonne in the baseline scenario to 86 Euro per tonne (see also Table 4), which is still above the most expensive alternatives as CCS.

In the third sensitivity analysis we make a different assumption about the collection costs, as these costs dominate the costs for plastic recycling. Two-thirds of the total compensation by the green dot company to municipalities for a tonne separated plastic is related to collection and transport costs. One of the problems with collection of plastic from households is that households separate relatively small volumes - about 15 kg per household per year in the Netherlands. As Dijkgraaf and Gradus (2015) show, there are several ways to decrease the collection costs of refuse collection. First, Dutch municipalities ${ }^{16}$ could introduce unit-based pricing of unsorted and compostable waste as a measure to stimulate the separate collection of recyclables. It is well-known that unit-based pricing systems are effective in stimulating recyclable waste such as plastics (see also Dijkgraaf and Gradus (2004) and Allers and Hoeben (2010)). Second, others claim that non-monetary initiatives as the provision of frequent curbside recycling services and reducing the residual waste collections frequency could encourage recycling as well. For US municipal data, Beatty et al. (2007) found a significant relation between the percentage of population served by curbside programs and the amount of recycled plastics. However, based on Dutch municipal data, Dijkgraaf and Gradus (2016) did not find a (significant) relationship between the frequency of collection of the plastics and the quantity of this material. More important is a separate bag or a bin, which significantly increases the amount of plastics separated. Third, privatization of refuse collection can be an alternative as well, as there was some evidence in the early literature that private companies provide a reduction in the costs to the taxpayer (see Dijkgraaf and Gradus (2003)). However, later analyses are more sceptical about cost savings due to privatisation, as market concentration can reduce cost savings (see Dijkgraaf and Gradus (2007)).

${ }^{16}$ Only one third of Dutch municipalities have a unit-based pricing system (see Dijkgraaf and Gradus (2015). 
In 2019, the compensation fee for municipalities of a tonne plastic is projected to be lowered from 670 Euro to 550 Euro per tonne. Therefore, the green dot company anticipates a (sharp) drop in the collection and transport costs for separated plastic. However, the exact fee will be renegotiated in 2017 and this decrease will serve as a lower bound. It must be noted that in this projection an expected change in the plastic price will already have been incorporated. Therefore, in the third sensitivity scenario, the fee in the year 2019 acts as the basis for the decrease in collection costs (a decrease from 670 Euro per tonne in 2015 to 550 Euro per tonne in 2019).

This increases the cost effectiveness from 172 to 68 Euro per tonne of $\mathrm{CO}_{2}$. Although in this scenario the cost will become substantially lower, the cost for a tonne of $\mathrm{CO}_{2}$ reduction is still significantly higher than the external costs as estimated in the literature (50 Euro per tonne of $\mathrm{CO}_{2}$ ).

Therefore, only a combination of the scenarios will lead to a price, which is lower than the estimated external costs. When combining the scenario of the indicated 2019 remuneration and the purchase of $\mathrm{CO}_{2}$-neutral energy, the resulting costs of $\mathrm{CO} 2$ reduction will be 40 Euro per tonne. Due to the fact that the indicated remuneration will be partially based on the expectations about the plastic price, this scenario already includes the potential changes in plastic prices and as such a combination is not realistic.

\section{CONCLUSIONS}

The reduced $\mathrm{CO}_{2}$ achieved by plastic recycling is extremely expensive if we compare this with conventional $\mathrm{CO}_{2}$ prices, external costs, and other possible technologies within the energy sector, such as wind energy and CCS. Based on a cost effectiveness analysis we show that the implicit price of reducing one tonne of $\mathrm{CO}_{2}$ is 172 Euro, which is substantially more than the current ETS prices or the external costs. We show that there are two reasons for this. First, the collection and treatment costs of plastic recycling are high. The collection costs of recycled plastics are almost seven times the costs of unsorted waste. In addition, the treatment costs of recycling are high, even if the 
(modest) revenues of recycled mixed plastics are taken into account. Second, the gains from $\mathrm{CO}_{2}$ emissions reduction through the recycling of plastic is not high. An average Dutch household separates 15 kilogram of plastics and thereby yearly saves 26 kilogram of $\mathrm{CO}_{2}$. It should be noticed that an average Dutch household should separate their plastics for roughly sixty years to compensate the $\mathrm{CO}_{2}$ of a single trip by airplane from Amsterdam to Los Angeles. Also based on a sensitivity analysis we show this main conclusion still holds if the main assumptions are relaxed. Our cost-effectiveness analysis is based on Dutch data, but it is also topical and applicable for other countries if an increasing amount of mixed plastics is recycled also due to proposed European legislation.

It is important to note that the policy recommendation is not that plastics should be incinerated. In order to increase innovation, and thus create the opportunity for cost reductions, policies should be focused on encouraging innovation in recycling in

plastics rather than focus on the simplistic goal of a percentage of plastic that needs to be recycled. In addition, we would suggest to analyse whether post-separation is an alternative. This technology allows for mechanical separation of waste, rather than requiring source-separation by householders. In the Netherlands such policies are not stimulated by the central government. However, post-separation can reduce costs, by increasing the plastic recovery levels and reducing collections costs of plastics. In the north of the Netherlands there are already some good results, as post-separation produces more kilograms of separated plastics by household and a higher quality of plastics, although insights in treatment costs are still lacking. This is important as it might lead to wind-fall profits as currently the post-separation industry gets the same fee for 1 tonne plastics as municipalities.

\section{REFERENCES}

Allers, M. and C. Hoeben (2010). Effects of unit-based garbage pricing: a differencesin-differences approach. Environmental and Resource Economics 45(3): 405-28.

Beatty, T., P. Berck and J.P. Shimshack (2007). Curbside recycling in the presence of alternatives, Economic Inquiry 45(4): 739-55.

Benner, J.H.B., Otten, M., Wielders, L.M.L. and Vroonhof, J.T.W. (2007). CO2kentallen afvalscheiding, CE Delft: Delft [in Dutch]. 
Bel, G., Joseph S (2015). Emissions Abatement: Untangling the Impacts of the EU ETS and the Economic Crisis, forthcoming in Energy Economics.

Bergsma, G.C., Bijleveld, M.M., Otten, M.B.J., and Krutwagen, B.T.J.M. (2011). LCA: recycling van kunststof verpakkingsafval uit huishoudens, CE Delft: Delft [in Dutch].

Da Cruz, N, S., Ferreira, M., Cabral, Simões, P. and R. Marques (2014). Packaging Waste recycling in Europe: Is the Industry paying for it? Waste Management 34: 298-308.

Dijkgraaf, E. (2004). Regulating the Dutch waste market, PhD thesis, EUR, Rotterdam.

Dijkgraaf, E. and H.R.J. Vollbergh (2004). Incineration or dumping? A social cost comparison of waste disposal options, Ecological Economics 50: 233-47.

Dijkgraaf, E. and R.H.J.M. Gradus (2003). Cost savings of contracting out refuse collection in the Netherlands, Empirica 30: 149-161.

Dijkgraaf, E. and R.H.J.M. Gradus (2004). Cost savings in unit-based pricing of household waste: the case of the Netherlands, Resource and Energy Economics 26(4): 353-71.

Dijkgraaf, E. and R.H.J.M. Gradus (2007). Collusion in the Dutch Waste Collection Market, Local Government Studies 33(4): 573-88.

Dijkgraaf, E. and R.H.J.M. Gradus (2015). Efficiency Effects of Unit-Based Pricing Systems and Institutional Choices of Waste Collection, Environmental and Resource Economics 61(4): 641-58.

Dijkgraaf, E. and R.H.J.M. Gradus (2016). An EU recycling target: what does the Dutch evidence tell us?, Will appear in Environmental and Resource Economics.

Dutch association of municipalities (2014a). Vergoedingen Vermarkting Kunststof Verpakkingsafval Huishoudens, Vereniging van Nederlandse Gemeenten: Den Haag [in Dutch].

Dutch association of municipalities (2014b). Ledenraadpleging: afspraken vergoedingen inzameling en post-collection kunststof verpakkingsafval, Vereniging van Nederlandse Gemeenten: Den Haag [in Dutch].

EEA (2008), External cost of electricity production, European Environment Agency. EU (2014), Impact Assessment Waste, Brussels (Appendix 4).

Eriksson, O., Carlsson R.M., Frostell, B., Björklund, A., Assefa, G., Sundqvist, J.-O., 
Granath J., Baky A and L. Thyselius (2005). Municipal solid waste management from a systems perspective, Journal of Cleaner Production 13: 241-252.

Groen, T., Harmsen, J., van Meijeren, J., de Ree, D., and Ton, J. (2012). Van spoor naar binnenvaart, TNO: Delft [in Dutch].

Greenpeace (2015). Factsheet kolenexit in Nederland. Amsterdam: 3 december [in Dutch].

Hopewell, J., R. Dvorak and E. Kosior (2009), Plastics recycling: challenges and opportunities, Philosophical Transactions of The Royal Society B Biological Sciences 364: 2215-2126.

KIDV (2016), Factcheck plastic recycling, Den Haag: 22 maart [in Dutch]

Marques, R. and N. Da Cruz (2015). Recycling and Extended Producer Responsibility: The European Experience, Ashgate: Dorchester (UK).

Morris, J. (1996). Recycling versus incineration: an energy conservation analysis. Journal of Hazardous Materials 47: 277-293.

Ministry of Economic Affairs (2013). Regeling vaststelling correcties voorschotverlening duurzame energieproductie 2014, Ministerie van Economische Zaken: Den Haag [in Dutch]

Miranda, M.L. and B. Hale (1997). Waste not, want not: the private and social costs of waste-to-energy production. Energy Policy 25(6): 587-600.

NVRD (2014). Benchmark afvalinzameling Benchmarkanalyse Peiljaar 2012, NVRD: Arnhem [in Dutch].

Rijkswaterstaat (2013). Afvalverwerking in Nederland: gegevens 2012, Rijkswaterstaat, Utrecht [in Dutch].

Roller, E. te (2011). Opslag CO2 onder Noordzee kan vanaf 2015. ChemieMagazine: October 2011, pp. 42-44.

Seltenrich, N. (2013). Incineration Versus Recycling: In Europe, A Debate Over Trash, http://e360.yale.edu/feature/incineration versus recycling in europe a debate over_trash/2686/

Tol, R.S.J. (2008). The Social Cost of Carbon: Trends, Outliers and Catastrophes, Economics 2, 2008-25.

Visser \& Smit Bouw (2010). Ketenanalyse Afvalverwerking, Visser \& Smit Bouw: Rotterdam. 
Warringa, G.E.A., de Bruyn, S.M. and Bijleveld, M.M. (2013). Inzetten op meer recycling, CE Delft: Delft [in Dutch]. 